\title{
PENGOLAHAN LINDI DENGAN PROSES OKSIDASI LANJUT BERBASIS OZON
}

\author{
Mohamad Rangga Sururi*), Siti Ainun, dan Amalia Krisna \\ Jurusan Teknik Lingkungan, Fakultas Teknik Sipil dan Perencanaan, Institut Teknologi Nasional \\ Jl. PKH Mustopha no.23, Bandung 40124, (022)7272215 \\ ")Penulis korespondensi : rangsoer@yahoo.com
}

\begin{abstract}
LEACHATE TREATMENT USING ADVANCE OXIDATION PROCESS BY OZONE. Landfilling technique gives negative impact due to its leacheate formation. Leacheate treatment in Indonesia is insiginificant because being dominated with biological system. This research aim is to find the effectivity of ozon process and its advance oxidation. Leacheate sample came from the inlet of the installation from Sarimukti Landfill which is being dilluted 10 times. The variation consists of $\mathrm{O}_{3}$, $\mathrm{O}_{3} / \mathrm{H}_{2} \mathrm{O}_{2} 0.6 \mathrm{gr} / \mathrm{L}$ and $\mathrm{O}_{3} / \mathrm{UV}$. The process runs for 3 hours with sampling every 30 minutes. The result shows that the leacheate have ratio of $B O D / C O D$ of 0.2. DHL values for three variations are decreasing with the same range of 8-11\%. The highest efficiency removal came from the combination of $\mathrm{O}_{3} / \mathrm{H}_{2} \mathrm{O}_{2} 0.6 \mathrm{gr} / \mathrm{L}$. Meanwhile the highest COD removal efficiency comes from $\mathrm{O}_{3} / \mathrm{H}_{2} \mathrm{O}_{2} 28.9 \%$. The excallation of $B O D$ is given by variation of $\mathrm{O}_{3}$ and $\mathrm{O}_{3} / U V$ which can be indicates that the process has been successfully to increase the biodegradability of leacheate. The $\mathrm{H}_{2} \mathrm{O}_{2}$ addition and UV exposure plays as an initiatior to the decomposition of ozone which formed the $\mathrm{OH}$ as the highest oxidator in water to enhance the better oxidation process. Meanwhile the complexity of leachate needs to be investigated further to shows its composition of organic compounds.
\end{abstract}

Keywords: advance oxidation process; leachate; $\mathrm{OH}$ radical; ozone decomposition rate; removal efficiency

\begin{abstract}
Abstrak
Dampak negatif TPA adalah timbulnya lindi dengan karakteristik yang kompleks. Pengolah lindi yang banyak digunakan di Indonesia adalah pengolahan biologi. Tujuan penelitian ini untuk mencari efektivitas teknik oksidasi dengan $\mathrm{O}_{3}$ dan oksidasi lanjut berupa $\mathrm{O}_{3} / \mathrm{H}_{2} \mathrm{O}_{2}$ 0,6 gr/L, serta $\mathrm{O}_{3} / \mathrm{UV}$. Sample lindi diambil dari inlet instalasi pengolah lindi TPA Sarimukti dengan pengenceran $10 \mathrm{kali}$. Reaktor dioperasikan selama 3 jam dengan interval per 30 menit. Hasil karakterisasi sampel memperlihatkan bahwa lindi memiliki nilai BOD/COD 0,2. Nilai DHL pada setiap perlakuan menunjukan tingkat penurunan 8-11\%. Tingkat penurunan terbesar yaitu pada proses $\mathrm{O}_{3} / \mathrm{H}_{2} \mathrm{O}_{2}$. Untuk penyisihan terhadap COD ketiga variasi memberikan trend yang sama. Efisiensi penyisihan COD tertinggi sebesar $28,9 \%$ adalah pada $\mathrm{O}_{3} / \mathrm{H}_{2} \mathrm{O}_{2}$. Peningkatan $\mathrm{BOD}$ untuk $\mathrm{O}_{3}$ dan $\mathrm{O}_{3} / \mathrm{UV}$ memberikan hasil yang relatif sama sehingga disimpulkan bahwa proses yang dilakukan sudah berhasil dalam meningkatkan biodegradibilitas lindi. Berdasarkan hasil konsentrasi sisa ozon, pengukuran DHL dan penyisihan COD, maka disimpulkan bahwa variasi $\mathrm{O}_{3} / \mathrm{H}_{2} \mathrm{O}_{2}$ memberikan hasil yang lebih baik. Penambahan $\mathrm{H}_{2} \mathrm{O}_{2}$ dan pemaparan sinar UV merupakan inisiator pada reaksi dekomposisi ozon sehingga terbentuk ${ }^{\circ} \mathrm{OH}$ yang merupakan bahan dengan daya oksidasi terbesar dalam airsehingga bisa meningkatkan proses oksidasi yang lebih baik.Karakteristik lindi yang kompleks menyebabkan diperlukan penelitian yang lebih dalam terkait dengan komposisi senyawa organik.
\end{abstract}

Kata kunci: teknik oksidasi lanjutan; lindi; radikal OH; laju dekomposisi ozon; efisiensi penyisihan

How to Cite This Article: Sururi, M.R., Ainun, S., dan Krisna, A., (2014) Pengolahan Lindi dengan Proses Oksidasi Lanjut Berbasis Ozon, Reaktor, 15(1), 20-26, http://dx.doi.org/ 10.14710/reaktor.15.1.20-26

\section{PENDAHULUAN}

Teknik pengurugan (landfilling) merupakan teknik pengolahan akhir sampah yang biasa digunakan di Indonesia, bahkan di dunia. Teknik pengurugan telah dibangun sebanyak 150.000 di seluruh dunia (Kurniawan dkk., 2006). Menurut AMPL (2008), 
salah satu isu utama bidang persampahan di Indonesia adalah menurunnya kualitas manajemen di Tempat Pemrosesan Akhir Sampah (TPAS), dimana TPAS yang didesain dengan sanitary landfill dan control landfill pada prakteknya menjadi open dumping.

Dampak negatif dari sistem pengurugan adalah timbulnya lindi akibat dari proses dekomposisi materi sampah dan air eksternal yang masuk ke dalam timbunan sampah. Lindi mengandung bahan organik baik yang biodegradable ataupun non biodegradable, mengandung ammonia, logam berat, bahkan berdasarkan tes toksikologi, lindi merupakan bahan yang berbahaya bagi kesehatan (Renou dkk., 2008).

Permasalahan lindi di Indonesia menjadi semakin kompleks dan menimbulkan permasalahan sosial, akibat penanganannya yang tidak tepat. Kondisi ini diperparah dengan diterapkannya sistem pengurugan open dumping yang dapat menyebabkan kuantitas lindi semakin besar. Menurut statistika persampahan tahun 2008, hanya $42 \%$ TPAS di Indonesia yang memiliki fasilitas pengolahan lindi yang berfungsi dengan baik, dan pada umumnya sistem pengolahan yang masih berfungsi adalah sistem pengolahan fisik-kimia, sementara pengolahan biologi yang masih berfungsi hanya $2 \%$ (Kementrian Lingkungan Hidup, 2008).

Pengolah lindi yang banyak digunakan di Indonesia hingga saat ini adalah kontak stabilisasi, yang dipilih berdasarkan kesederhanaan serta iklim tropis yang cukup panas. Salah satu kekurangan dari pengolahan biologi yaitu membutuhkan lahan yang luas (Wu dkk., 2004). Lebih lanjut, karakter lindi akan berubah sesuai dengan umur timbulan sampah, sehingga proses pengolahan harus menyesuaikan dengan perubahan karakter lindi tersebut. Lindi merupakan limbah yang sulit untuk secara langsung diolah secara biologi (Cortez dkk., 2010; Mahmud dkk., 2012).

Teknik oksidasi lanjut merupakan teknik yang dapat diterapkan untuk menyisihkan warna, mengurangi kandungan bahan organik, serta merubah lindi menjadi lebih mudah didegradasi (Renou dkk., 2008). Ozon merupakan salah satu oksidator yang kuat memiliki nilai $\mathrm{E}^{0}$ sebesar 2,07 Volt, bahkan ozon akan terdekomposisi menjadi $\mathrm{OH}$-yang merupakan oksidator terkuat di dalam air dengan nila $\mathrm{E}^{0}$ sebesar 2,8 Volt. Proses ozonisasi maupun proses oksidasi lanjut dengan mempercepat dekomposisi ozon menjadi $\mathrm{OH}$, merupakan salah satu upaya yang dianggap akan efektif untuk mengolah lindi. Adapun reaksi dekomposisi ozon adalah (Von Gunten, 2003):

$$
\begin{gathered}
\mathrm{O}_{3}+\mathrm{OH}^{-} \rightarrow \mathrm{HO}_{2}^{-}+\mathrm{O}_{2} \\
\mathrm{O}_{3}+\mathrm{HO}_{2}^{-} \rightarrow \mathrm{OH}^{\cdot}+\mathrm{O}_{2} \cdot+\mathrm{O}_{2}
\end{gathered}
$$

Pada penelitian ini akan diteliti dan dibandingkan penyisihan lindi dengan teknik ozonisasi konvensional dan oksidasi lanjut (AOP) berupa $\mathrm{O}_{3} / \mathrm{H}_{2} \mathrm{O}_{2}$, serta $\mathrm{O}_{3} / \mathrm{UV}$. Sampel lindi berasal dari tumpukan sampah yang muda, tepatnya dari TPA
Sarimukti Bandung. Tujuan dari penelitian ini adalah untuk identifikasi pengaruh karakteristik lindi, mengetahui respon sampel lindi ketika proses berlangsung serta efektifitas proses ozonisasi konvensional dan AOP berbasiskan ozon melalui parameter kunci berupa BOD, COD, Daya Hantar Listrik (DHL) serta Total Organic Carbon (TOC).

\section{METODE PENELITIAN}

Sampel berasal dari TPAS Sarimukti yang terletak di Kecamatan Cipatat Kabupaten Bandung Barat, memiliki luas 25,2 Ha serta memproses sampah sebanyak 1.200 ton/hari. TPAS ini melayani sebagian besar sampah dari Cekungan Bandung, terutama wilayah Kota Bandung, Kota Cimahi dan Kabupaten Bandung Barat. Sampel lindi yang digunakan berasaldari Inlet unit pengolahan lindi TPAS Sarimukti. Sebelum diteliti sampel tersebut terlebih dahulu diencerkan sebanyak 10 kali.

Penelitian akan dilakukan secara semi batch, dimana suplai gas ozon akan dilakukan secara menerus ke kontaktor batch yang berisi lindi sebanyak 1 liter. Percobaan semi batch akan memberikan informasi mengenai titik kritis penurunan konsentrasi dengan gradien terbesar, sebelum mengalami kelandaian (Fernando, 1995). Rangkaian alat penelitian yang digunakan pada penelitian ini adalah tabung oksigen dengan kapasitas $1 \mathrm{~m}^{3}$, yang akan mengalirkan $\mathrm{O}_{2}$ dengan debit sebesar $3 \mathrm{~L} /$ menit ke ozon generator. Oksigen akan dirubah menjadi ozon pada ozon generator tipe $0 Z \mathrm{~F}-1 \mathrm{G}$, dengan daya $200 \mathrm{~W}$ dan tegangan 220 Volt. Selanjutnya, ozon pada fase gas akan dilarutkan pada ozon kontaktor, dimana sampel disimpan sebanyak 1 liter. Ozon kontaktor dilengkapi filter disc dengan diameter pori 60-100 $\mu \mathrm{m}$. Ozon kontaktor juga dilengkapi dengan valve yang berguna untuk pengambilan sampel air setiap 30 menit selama 180 menit. Ozon yang masih tersisa pada fase gas akan diuraikan pada ozon dekomposer yang berisi larutan KI.

Pada proses AOP dengan $\mathrm{O}_{3} / \mathrm{H}_{2} \mathrm{O}_{2}$, maka pada kontaktor akan ditambahkan $\mathrm{H}_{2} \mathrm{O}_{2}$ sebanyak $0,6 \mathrm{gr} / \mathrm{L}$, sementara pada proses AOP dengan $\mathrm{O}_{3} / \mathrm{UV}$ akan dipaparkan sinar UV yang berasal dari lampu UV C berdaya 15 watt yang memiliki panjang gelombang kurang dari $280 \mathrm{~nm}$. Lampu ini berfungsi untuk mempercepat pembentukan $\mathrm{OH} \cdot$ dalam air. Jarak sinar lampu UV dengan kontaktor yaitu sebesar $10 \mathrm{~cm}$. Skema rangkaian alat penelitian ditampilkan pada Gambar 1.

Pengukuran konsentrasi sisa ozon pada fase cair dilakukan berdasarkan standard metode $4500-\mathrm{O}_{3}$ yaitu dengan metode Indigo Calorimetric Methode (ICM). Pemeriksaan TOC dilakukan di Laboratorium air PDAM Kota Bandung dan hanya dilakukan pada sampel awal dan pada titik kritis ketika efisiensi pengolahan tercapai pada proses ozonisasi konvensional. 


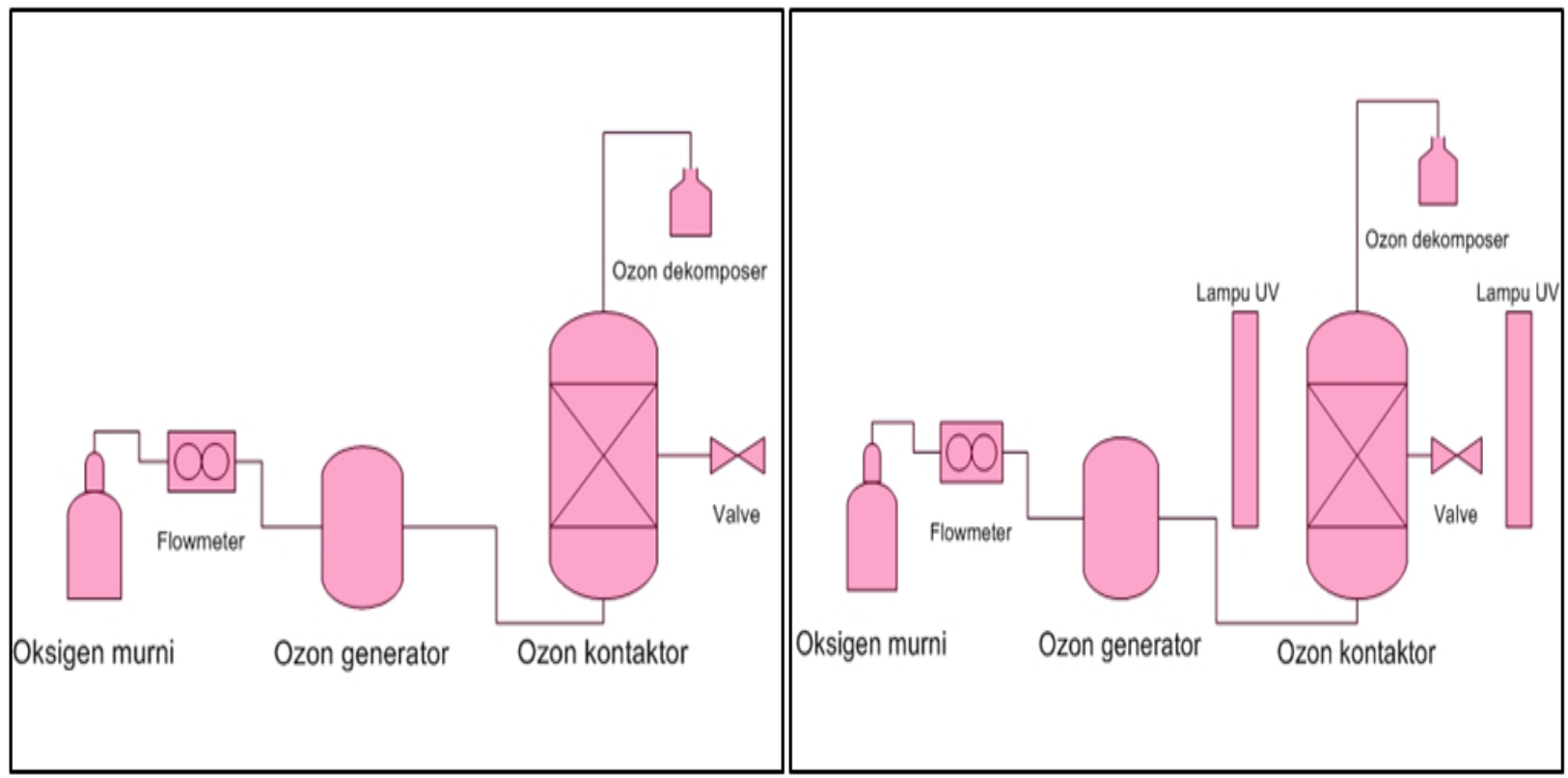

a

Gambar1. Skema alat yang digunakan (a) $\mathrm{O}_{3} / \mathrm{H}_{2} \mathrm{O}_{2} ;$ (b) $\mathrm{O}_{3} / \mathrm{UV}$

Tabel 1. Kerangka penelitian

\begin{tabular}{lll}
\hline \multicolumn{1}{c}{ Parameter Variasi } & \multicolumn{1}{c}{ Kondisi } \\
\hline Ozonisasi konvensional & $\begin{array}{l}\text { Proses ozonisasi dilakukan tanpa penambahan perlakuan } \\
\text { apapun }\end{array}$ \\
$\mathrm{AOP} \mathrm{O}_{3} / \mathrm{H}_{2} \mathrm{O}_{2}$ & $\begin{array}{l}\text { Penambahan } \mathrm{H} 2 \mathrm{O} 2 \text { sebanyak } 0,6 \mathrm{gr} / \mathrm{L} \\
\text { Pemaparan lampu UV pada kontaktor dengan jarak } 10 \mathrm{~cm}\end{array}$ \\
$\mathrm{AOP} \mathrm{O}_{3} / \mathrm{UV}$ & & Kondisi \\
\hline \multicolumn{1}{c}{ Parameter Tetap } & Semi Batch \\
Reaktor & $1 \mathrm{~L}$ & \\
Volume sampel & $3 \mathrm{~L} /$ menit, disuplai menerus \\
Debit Gas & 10 kali \\
Pengenceran Lindi & 180 menit \\
Waktu Kontak & pH, alkalinitas, BOD; COD; dan DHL \\
Parameter yang diukur &
\end{tabular}

Efektifitas proses ozonisasi konvensional dan AOP akan ditentukan berdasarkan pengukuran parameter BOD, COD, dan Daya Hantar Listrik (DHL) pada setiap interval 30 menit selama 180 menit. Perubahan $\mathrm{pH}$ dan alkalinitas juga diukur untuk melihat respon dari lindi terhadap variasi proses ozonisasi. Kerangka penelitian dapat dilihat pada Tabel 1.

\section{HASIL DAN PEMBAHASAN}

\section{Karakterisasi Sampel Lindi}

Karakteristik lindi TPA Sarimukti setelah diencerkan dapat dilihat pada Tabel 2. Alkalinitas merupakan kemampuan air untuk menetralkan asam. Nilai total alkalinitas pada sampel lindi sangat tinggi yaitu $1300 \mathrm{mg} / \mathrm{L}$ yang dimungkinkan karena konsentrasi ammonia yang tinggi pula. Alkalinitas menyatakan adanya kandungan senyawa karbonat dan bikarbonat. Senyawa ini pada proses ozonisasi air lindi berfungsi sebagai inhibitor (Fernando, 1995), akibatnya proses reaksi berantai dekomposisi ozon menjadi $\mathrm{OH} \cdot$ dapat terhambat (Von Gunten, 2003), seperti pada reaksi di bawah:

$$
\begin{gathered}
\mathrm{OH} \cdot+\mathrm{CO}_{3} \rightarrow \mathrm{CO}_{3} \cdot+\mathrm{OH}^{-} \\
\mathrm{OH} \cdot+\mathrm{HCO}_{3} \rightarrow \mathrm{CO}_{3} \cdot+\mathrm{H}_{2} \mathrm{O}
\end{gathered}
$$

Reaksi 3 dan 4 memberikan informasi bahwa reaksi antara karbonat atau bikarbonat dengan $\mathrm{OH}$. menghasilkan $\mathrm{CO}_{3} \cdot$ yang akan menghentikan reaksi berantai (Von Gunten, 2003).

Tabel 2. Karakteristik sampel Lindi TPA Aktif

\begin{tabular}{lll}
\hline Parameter & \multicolumn{1}{c}{ Satuan } & \multicolumn{1}{c}{ Nilai } \\
\hline $\mathrm{Suhu}$ & ${ }^{\circ} \mathrm{C}$ & 23 \\
$\mathrm{pH}$ & - & 8,7 \\
Alkalinitas & $\mathrm{mg} \mathrm{CaCO} / \mathrm{L}$ & 1300 \\
Amonia & $\mathrm{mg} / \mathrm{L}$ & $6.906,72$ \\
$\mathrm{COD}$ & $\mathrm{mg} \mathrm{O} / \mathrm{L}$ & 213,4 \\
$\mathrm{BOD}$ & $\mathrm{mg} \mathrm{O} 2 / \mathrm{L}$ & 42,9 \\
$\mathrm{DHL}$ & $\mu \mathrm{S} / \mathrm{cm}$ & 51,2 \\
TOC & $\mathrm{mg} / \mathrm{L}$ & 85,58 \\
\hline
\end{tabular}


Kandungan amonia pada sampel lindi sangatlah tinggi hal ini menunjukan terjadinya proses amonifikasi, dikarenakan $70 \%$ komposisi sampah di Indonesia adalah bahan organik (Raharjo, 2009), sehingga bakteri heterotropik akan merubah organik nitrogen dalam tumpukan sampah menjadi amonia. Konsentrasi tersebut termasuk dalam kisaran amonia yang terkandung dalam lindi pada TPA aktif seperti yang disebutkan oleh Renou (2008) yaitu dapat mencapai $13.000 \mathrm{mg} / \mathrm{L}$.

Kandungan TOC pada sampel sebesar 85,58 $\mathrm{mg} / \mathrm{L}$. Perbandingan BOD/COD pada sampel hanya 0,2 , hal ini mengindikasikan lindi didominasi oleh kandungan bahan organik non-biodegradble. Rasio $\mathrm{BOD}_{5} / \mathrm{COD}$ yang kurang dari 0,5 , mengindikasikan proses pengolahan sebaiknya tidak menggunakan proses biologi namun fisik-kimia (Tchobanoglous dkk., 2003).

Parameter DHL mengindikasikan kandungan anion dan kation untuk menghantarkan arus listrik yang dialirkan ke dalam air terkandung pada sampel yaitu sebesar $51,2 \mu \mathrm{S} / \mathrm{cm}$ yang merupakan pengukuran hasil pengenceran 10 kali. Nilai tersebut termasuk kategori rendah jika dibandingkan dengan lindi dari TPA lainnya di Indonesia yaitu sekitar 1.000-40.000 $\mu \mathrm{S} / \mathrm{cm}$. Ion-ion utama yang menyebabkan kandungan daya hantar listrik adalah ion hydrogen $\mathrm{H}^{+}$dan hidroksida $\mathrm{OH}^{-}$selain dari adanya kandungan fosfat dan nitrat. Kedua ion tersebut memiliki peran dalam proses ozonisasi seperti pada reaksi (1) dan (3).

\section{Konsentrasi sisa ozon}

Konsentrasi sisa ozon pada proses ozonisasi konvensional, $\mathrm{O}_{3} / \mathrm{H}_{2} \mathrm{O}_{2}$ dan $\mathrm{O}_{3} / \mathrm{UV}$ dapat dilihat pada Gambar 2.

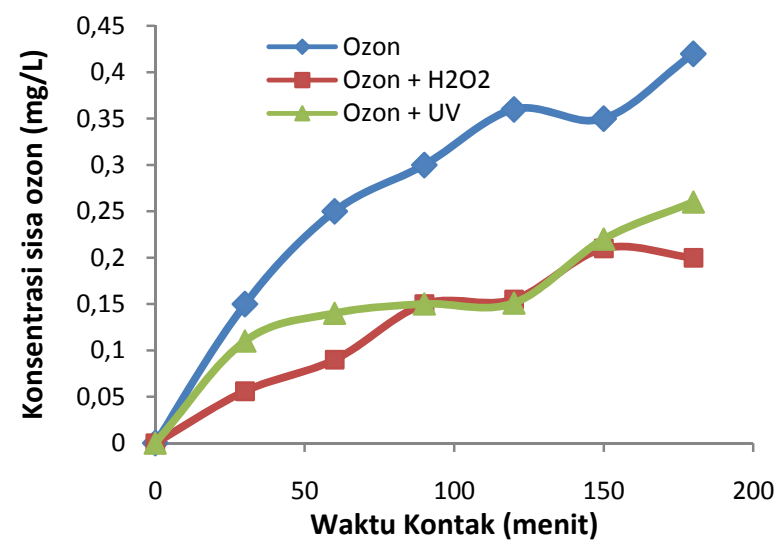

Gambar 2. Konsentrasi sisa ozon pada proses ozonisasi konvensional dan AOP

Pada gambar tersebut, setelah menit ke-30, terlihat perbedaan konsentrasi sisa ozon yang signifikan antara proses konvensionaldan proses AOP. Terlihat bahwa pada proses AOP laju dekomposisi ozon lebih cepat dibandingkan dengan ozonisasi konvensional. Penambahan $\mathrm{H}_{2} \mathrm{O}_{2}$ berperan sebagai inisiator pada reaksi dekomposisi ozon sehingga terbentuk $\mathrm{OH}^{\cdot}$ yang merupakan bahan dengan daya oksidasi terbesar dalam air (Von Gunten, 2003). Ketika $\mathrm{H}_{2} \mathrm{O}_{2}$ dilarutkan dalam air, maka akan terdisosiasi menjadi ion hidroperoksida, lalu akan menghasilkan radikal superoksida yang merupakan promotor reaksi berantai (Von Gunten, 2003).

$$
\begin{gathered}
\mathrm{H}_{2} \mathrm{O}_{2} \rightarrow \mathrm{HO}_{2}^{-}+\mathrm{H}^{+} \\
\mathrm{HO}_{2}^{-}+\mathrm{O}_{3} \rightarrow \mathrm{H}^{\bullet}+\mathrm{O}_{2}^{\bullet-}+\mathrm{O}_{2}
\end{gathered}
$$

Proses $\mathrm{O}_{3} / \mathrm{UV}$ memiliki trend nilai konsentrasi sisa ozon yang hampir sama dengan $\mathrm{O}_{3} / \mathrm{H}_{2} \mathrm{O}_{2}$. Sinar UV yang diberikan pada sampel akan diserap oleh ozon dan menghasilkan $\mathrm{H}_{2} \mathrm{O}_{2}$ sebagai hasil intermediate yang kemudian akan terdekomposisi menjadi $\mathrm{OH}$ radikal. Reaksi yang terjadi antara ozon dengan UV dapat dilihat pada persamaan reaksi dibawah ini (Savant, 2003):

$$
\begin{gathered}
\mathrm{O}_{3}+\mathrm{UV}+\mathrm{H}_{2} \mathrm{O} \rightarrow \mathrm{H}_{2} \mathrm{O}_{2}+\mathrm{O}_{2} \\
\mathrm{H}_{2} \mathrm{O}_{2}+\mathrm{UV} \rightarrow 2 \mathrm{OH} \cdot
\end{gathered}
$$

\section{Perubahan pH dan Alkalinitas}

Respon lindi pada proses ozonisasi diukur melalui dinamika $\mathrm{pH}$, dan alkalinitas pada proses ozonisasi konvensional dan proses AOP. Derajat keasaman, merupakan parameter universal yang digunakan untuk mengukur intensitas asam dan basa dari larutan. Lebih dari itu, pengukuran $\mathrm{pH}$ merupakan cara untuk mengukur konsentrasi ion $\mathrm{H}$, lebih tepatnya aktifitas ion H. Sementara alkalinitas menyatakan kandungan bahan karbonat dan bikarbonat yang terdapat pada sampel. $\mathrm{pH}$ lindi merupakan parameter penting karena ion hidroperoksida menginisiasi dekomposisi ozon. Sementara karbonat dan bikarbonat dapat menghambat reaksi dekomposisi ozon.

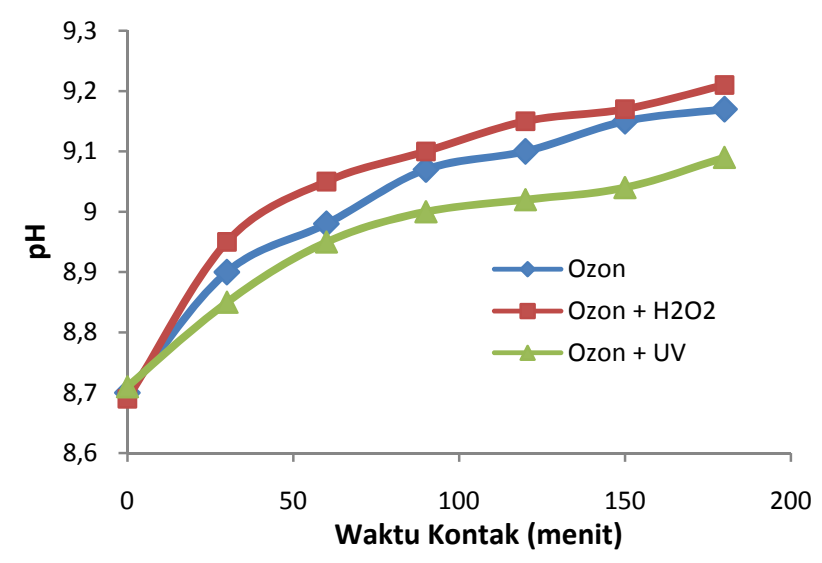

Gambar 3. Perubahan $\mathrm{pH}$ pada proses ozonisasi konvensional dan AOP

Gambar 3 menunjukan $\mathrm{pH}$ air meningkat seiring penambahan waktu kontak pada setiap proses yang ada. Perbedaan $\mathrm{pH}$ antara ke-3 proses tidaklah besar. Pada proses ozonisasi, kenaikan $\mathrm{pH}$ selalu memiliki efek yang positif terhadap penyisihan COD (Fernando, 1995), tergantung dari jenis reaksi yang berlangsung. Berdasarkan Fernando (1995), pada reaksi langsung, kenaikan $\mathrm{pH}$ mengindikasikan 
adanya kehadiran senyawa yang dapat langsung beraksi dengan ozon seperti ditunjukkan pada reaksi 1 . Reaksi tidak langsung, terjadi antara produk dekomposisi ozon yaitu $\mathrm{OH} \cdot$ dengan senyawa lainnya. Reaksi ini terjadi ketika $\mathrm{OH}^{\cdot}$ yang dihasilkan dari reaksi 2 bereaksi dengan senyawa yang terdapat pada lindi. Sehingga dapat disimpulkan bahwa kenaikan $\mathrm{pH}$ dapat terjadi pada reaksi antara ozon secara langsung ataupun pada produk dekomposisinya yaitu $\mathrm{OH}^{\cdot}$ dengan senyawa yang terdapat pada lindi. Kenaikan nilai $\mathrm{pH}$ hingga pada kisaran range 8-9 akan mempercepat proses dekomposisi ozon (Kurniawan dkk., 2006) seperti terlihat pada Gambar 2.

Hasil pengukuran alkalinitas menunjukkan fenomena yang berbeda dengan $\mathrm{pH}$, alkalinitas mengalami penurunan seperti terlihat pada Gambar 4 . Seperti ditunjukan pada reaksi 3 dan 4, pada proses ozonisasi menurut Acero dan Von Gunten (2000), karbonat dan bikarbonat dapat bereaksi dengan produk dekomposisi ozon dan menghasilkan karbonat radikal yang menjadi pemutus reaksi berantai pembentukan $\mathrm{OH}$. Oleh karena itu karbonat dan bikarbonat akan digunakan sebagai reaktan pada proses ozonisasi baik konvensional maupun AOP sehingga akan mengalami penurunan konsentrasi seiiring penambahan waktu kontak.

Percobaan dilakukan secara semi batch. Gambar 3 dan 4 menunjukan perubahan $\mathrm{pH}$ dan alkalinitas memiliki perbedaan gradien pada menit ke 90, dimana perubahan $\mathrm{pH}$ dan alkalinitas setelah menit tersebut lebih landai dibandingkan sebelum menit ke90.

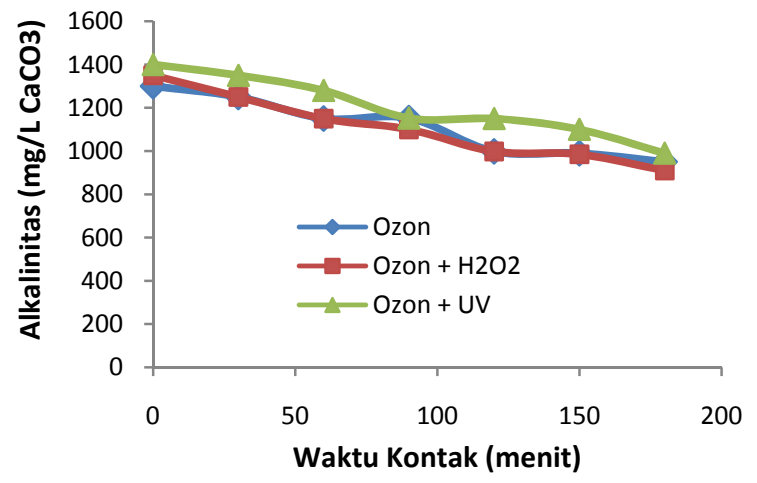

Gambar 4. Perubahan alkalinitas pada proses ozonisasi konvensional dan AOP

\section{Efektifitas proses ozonisasi konvensional dan AOP}

Pengukuran DHL mengindikasikan pengukuran bahan anorganik dalam sampel lindi, sementara pengukuran COD mengindikasikan penurunan bahan organik pada sampel lindi. Konduktivitas dapat menunjukkan jumlah kehadiran ion secara total, pergerakan dan valensi ionnya. Tingginya kandungan DHL biasanya menunjukkan tingkat pencemaran pada air. Berdasarkan Sehah (2008), air lindi diindikasikan banyak mengandung senyawa asam, basa dan garam yang terlarut sehingga terpecah menjadi ion positif dan ion negatif yang meningkatkan DHL. Kandungan DHL pada sampel setelah diencerkan adalah 51,2 $\mu \mathrm{S} / \mathrm{cm}$, dimana menurut Pidriansy (2012), kandungan DHL pada sekitar sumur terdekat dengan TPA berkisar 132,5 dan $1420 \mu \mathrm{S}$ cm-1 dan tergolong tinggi.

DHL merupakan indikator adanya kandungan zat- zat terlarut berupa kation dan anion yang bisa menghantarkan arus listrik. Pada Gambar 5, untuk ketiga variasi proses, terjadi penurunan DHL dengan nilai yang tidak berbeda secara signifikan, yaitu antara 45,8-47,1 $\mu \mathrm{mhos} / \mathrm{L}$ atau turun sekitar $8-11 \%$ dari kondisi awal. Meskipun demikian penurunan yang terbesar ada pada proses $\mathrm{O}_{3} / \mathrm{H}_{2} \mathrm{O}_{2}$.

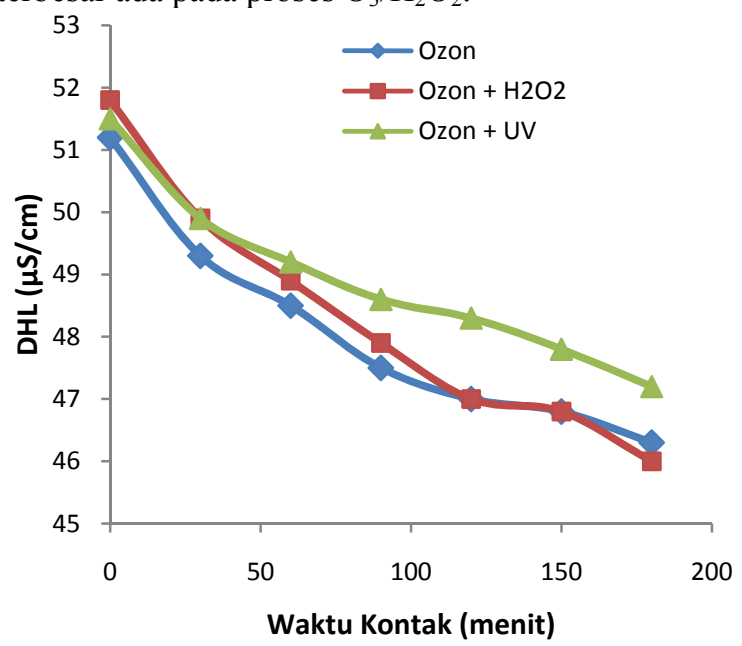

Gambar 5. Pengukuran DHL

Penurunan DHL terjadi akibat dari terlepasnya kation dan anion yang kemudian mengendap dalam kondisi basa, dimana berdasarkan Gambar 3, pH mengalami kenaikan hingga diatas 9 pada seluruh proses. Fenomena ini menguatkan penelitian Rezagama dan Notodarmojo (2012).

Grafik pengukuran COD dapat dilihat pada Gambar 6. Berdasarkan gambar tersebut, ketiga variasi memberikan trend dengan kecenderungan yang sama. Gambar 6 memberikan informasi, pada seluruh variasi, terdapat dua tahapan penyisihan. Titik kritis pada proses ozonisasi konvensional yaitu pada menit ke-60, dimana konsentrasi COD mencapai $275 \mathrm{mg} / \mathrm{L}$, sementara hingga menit ke 180 efisiensi penurunan COD mencapai $18,74 \%$. Pada proses $\mathrm{O}_{3} / \mathrm{UV}$, titik kritis terjadi hingga menit ke 120, dimana COD turun hingga 264,41 mg/L. Hasil terbaik ditunjukan oleh proses $\mathrm{O}_{3} / \mathrm{H}_{2} \mathrm{O}_{2}$, dimana titik kritis terjadi pada menit ke 150, COD turun hingga mencapai $231,46 \mathrm{mg} / \mathrm{L}$ $(28,9 \%)$. Sebagai perbandingan, maka dilakukan pengukuran TOC pada titik kritis pada proses ozonisasi konvensional, dan nilai TOC turun sebesar $46 \%$ menjadi 44,65 mg/L. Fenomena tersebut dipengaruhi oleh konsentrasi sisa ozon. Nilai konsentrasi sisa ozon yang lebih kecil mengindikasikan jumlah $\mathrm{OH} \cdot$ yang lebih dominan dan dominasi produk dekomposisi itu secara berturut turut dominan pada proses $\mathrm{O}_{3} / \mathrm{H}_{2} \mathrm{O}_{2}$, kemudian $\mathrm{O} 3 / \mathrm{UV}$ dan ozonisasi konvensional. Proses ozonisasi yang disertai penambahan $\mathrm{H}_{2} \mathrm{O}_{2}$ akan menghasilkan proses dimana 
$\mathrm{OH}^{\cdot}$ akan lebih dominan dibandingkan dengan ozon itu sendiri, sehingga spesies ini akan lebih dominan berperan pada proses ini dengan daya oksidasi yang lebih baik (Cortez, dkk, 2010).

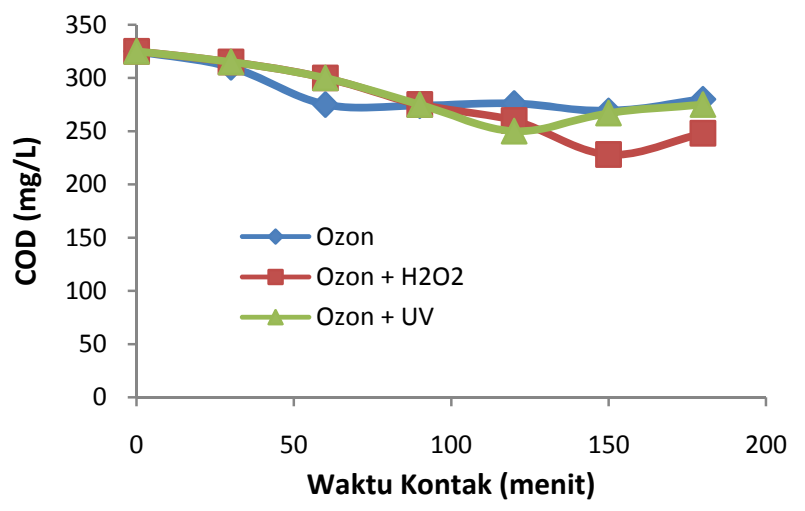

Gambar 6. Pengukuran COD

Reaksi tidak langsung melalui $\mathrm{OH} \cdot$ berperan lebih dominan dalam penyisihan bahan organik untuk menghasilkan efisiensi penyisihan yang lebih baik. Penelitian ini menguatkan hasil penelitian Renou (2008), dimana teknik oksidasi lanjut merupakan teknik yang dapat diterapkan untuk menyisihkan kandungan bahan organik.

Reaksi antara $\mathrm{OH} \cdot$ dan bahan organik dapat menyebabkan efek terhadap stabilitas ozon. Setelah reaksi antara $\mathrm{OH}^{\cdot}$ dan bahan organik terjadi maka fraksi dari bahan organik menjadi carbon center radical. Reaksi carbon center radical dengan oksigen akan menyebabkan pembentukan superoxide radical, yang akan bereaksi dengan ozon membentuk $\mathrm{OH}$ radikal kembali (Von Gunten, 2003).

Parameter lain yang mengukur tingkat efektivitas proses ozon adalah BOD yang menunjukkan indikator bahan organik yang bisa di degradasi secara biologi. Hasil pengukuran BOD untuk ketiga variasi dapat dilihat pada Gambar 7.

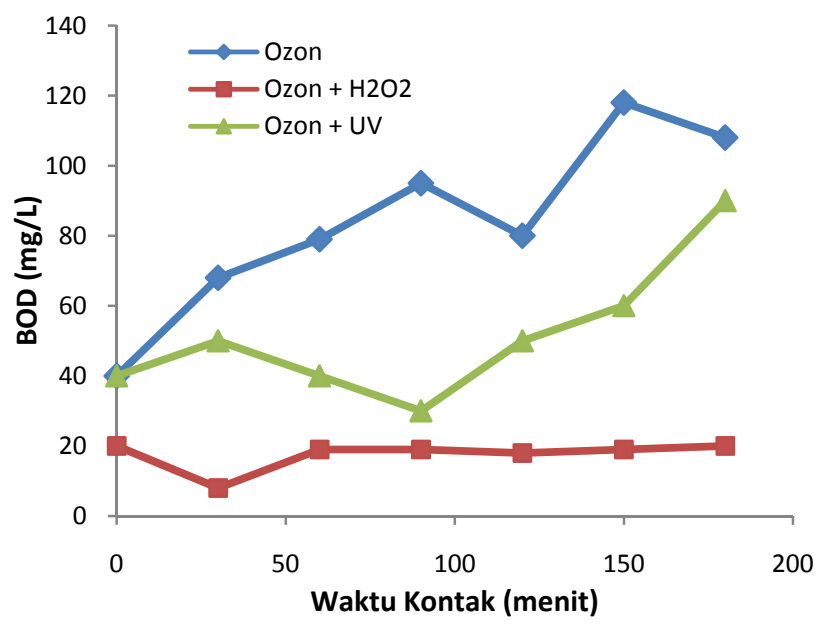

Gambar 7. Pengukuran BOD
Berdasarkan Gambar 7 terlihat bahwa terjadi peningkatan BOD untuk variasi ozon konvensional dan variasi $\mathrm{O}_{3} / \mathrm{UV}$. Variasi $\mathrm{O}_{3} / \mathrm{H}_{2} \mathrm{O}_{2}$, terjadi deviasi terlihat dimana pada menit ke nol terjadi perbedaan yang signifikan dengan kedua variasi lainnya. Hal ini disebabkan karena ternyata dalam metoda pengukuran BOD yang digunakan, senyawa $\mathrm{H}_{2} \mathrm{O}_{2}$ diduga dapat berperan sebagai senyawa pengganggu terhadap pengukuran BOD.

Gambar 7 memberikan indikasi bahwa proses yang dilakukan sudah berhasil dalam meningkatkan biodegradibilitas lindi. Peningkatan BOD dengan proses ozon konvensional memberikan hasil yang lebih baik dari AOP. Proses penyisihan bahan organik secara langsung dengan ozon diduga bisa meningkatkan tingkat biodegradibilitas lindi. Di sisi lain proses AOP seharusnya memberikan hasil yang lebih baik dibandingkan ozonisasi konvensional karena proses tersebut menginisiasi pembentukan $\mathrm{OH}$. Adanya radiasi UV tidak hanya mengaktifkan molekul ozon untuk membentuk $\mathrm{OH}$ radikal tetapi juga membuat senyawa organik mudah untuk dioksidasi (Li dkk., 2010). Fenomena tersebut mengindikasikan perlunya penelitian lanjutan untuk meneliti proses AOP terhadap penyisihan BOD, karena proses AOP melalui ozonisasi dapat meningkatkan kualitas lindi hingga siap untuk didegradasi secara biologi (Tizaoui dkk., 2007). Tizaoui (2007) menyatakan bahwa penambahan $\mathrm{H}_{2} \mathrm{O}_{2}$ memerlukan dosis optimum untuk proses oksidasi, sementara pada proses $\mathrm{O}_{3} / \mathrm{UV}$, diperlukan penelitian lanjutan mengenai jarak antara sumber sinar UV dan ozon kontaktor.

\section{KESIMPULAN}

Proses ozonisasi pada lindi akan menaikan nilai $\mathrm{pH}$ sementara alkalinitas akan menurun. Pengolahan lindi dapat dilakukan dengan proses ozonisasi konvensional maupun AOP berbasiskan ozon. Proses AOP dapat meningkatkan proses dekomposisi ozon, sehingga $\mathrm{OH}^{\cdot}$ akan lebih dominan mengoksidasi polutan yang terdapat pada lindi.

Proses ozonisasi dan AOP bisa digunakan untuk menyisihkan DHL dan COD, sebaliknya BOD akan meningkat dan menunjukan biodegrabilitas lindi meningkat sehingga lebih siap untuk pengolahan lanjutan berupa pengolahan biologi. Hasil terbaik pengolahan lindi ditunjukan pada proses $\mathrm{O}_{3} / \mathrm{H}_{2} \mathrm{O}_{2}$.

\section{UCAPAN TERIMA KASIH}

Ucapan terima kasih ditujukan kepada Direktur Penelitian dan Pengabdian kepada Masyarakat Direktorat Jenderal Pendidikan Tinggi (DP2M Ditjen Dikti) Kementerian Pendidikan dan Kebudayaan Tahun Anggaran 2013 yang telah membiayai penelitian ini sebagai Penelitian Hibah Bersaing

\section{DAFTAR PUSTAKA}

Acero, J.L. and Von Gunten, U., (2000), Influence of carbonate on the ozone/hydrogen peroxide based 
advanced oxidation process for drinking water treatment, Ozone Science and Engineering, 22, pp. 305-328.

AMPL, (2008), Sinkronisasi Kebijakan Pengelolaan Persampahan di Indonesia, AMPL.or.id diakses 06 Januari 2014

Cortez, S., Teixeira, P., Oliveira, R., and Mota, M., (2010), Ozonationas polishing treatment of mature landfill leacheate, Journal of Hazardous Material, 182, pp. 730-734.

Fernando, B.J., (1995), Ozone reaction kinetic for water and wastewater system, CRC Press company, Washington DC, pp 11-12.

Kementrian Lingkungan Hidup, (2008), Statistik Persampahan Indonesia, Kementrian Lingkungan Hidup, Jakarta Indonesia, pp 16-17.

Kurniawan, T.A., Wai-Hung, L., and Chan, G.Y.S., (2006), Radical Catalayzed Oxidation Reaction for Degradation of Recalcitrant Compound From Landfill Leacheate, Chemical Engineering Journal, 125, pp. 35-57.

Li, W., Zhou, Q., and Hua, T., (2010), Removal of Organic Matter from Landfill Leachate by Advanced Oxidation Processes : A Review, International Journal of Chemical Engineering, 2010, pp 1-10.

Mahmud, K., Hossein, D.M.D., and Shams,S., (2012), Different Treatment Strategies for Highly Polluted Landfill Leacheate in Developing Countries, Journal Waste Management, 32, pp. 2096-2105.

Pidriansy, Q., (2013), Kajian Pencemaran Air Tanah Dangkal Dan Analisis Resiko Kesehatan Manusia Akibat Lindi Dari Landfill,Tesis Magister, Institut Teknologi Bandung, Bandung.
Raharjo, S., (2009), Perbaikan Pengelolaan Sampah di Indonesia, Jurnal Inovasi Online, 14/XXI/Juli 2009, pp 19-22.

Renou, S., Givaudan, J. G., Poulain, S., Dirrasouyan, F., and Moulin, P., (2008), Landfill leacheate treatment: Review and opportunity, Journal of Hazardous Materials, 150 (3), pp. 468-493.

Rezagama, A. dan Notodarmojo, S., (2012), Kinetika Transfer Ozondan Tren Kekeruhandalam Air Lindidengan Pengolahan Ozonisasi, ejournal.undip, di akses tanggal 8 Agustus 2014

Savant, G., (2003), Combine Ozone And Ultraviolet Inactivation Of Escherichia Coli, Master of Science Thesis, Mississipi State University, Mississipi.

Sehah dan Cahyanto, W.T., (2009), Pengujian Daya Hantar Listrik Air Tanah Di Sekitar Tempat Pembuangan Akhir Gunung Tugel Kabupaten Banyumas Menggunakan Prinsip Jembatan Wheatstone, Jurnal Molekul, 4(1), pp. 39-41.

Tizaoui, C., Bouselmi, L., Mansouri, L., and Ghrabi, A., (2007), Landfill leachate treatment with ozone and ozone/hydrogen peroxide system, Journal of Hazardous Materials, 140, pp. 316-324.

Tchobanoglous, G., Burton, F.L., and Stensel, D.H., (2003), Wastewater Engineering Treatment and Reuse, $4^{\text {th }}$, McGraw-Hill Company, Inc, Metcalf and Eddy Hongkong,pp 96-97

Von Gunten, U., (2003), Ozonitation of drinking water: Part I. Oxidation kinetics and product formation. Water Research, 37 (7), pp. 1443-1467.

Wu, J.J., Wu, C., Ma, H., and Chang, C., (2004), A Short Communication Treatment of landfill leachate by ozone-based advanced oxidation processes, Journal of Chemosphere, 54, pp. 997-1003. 